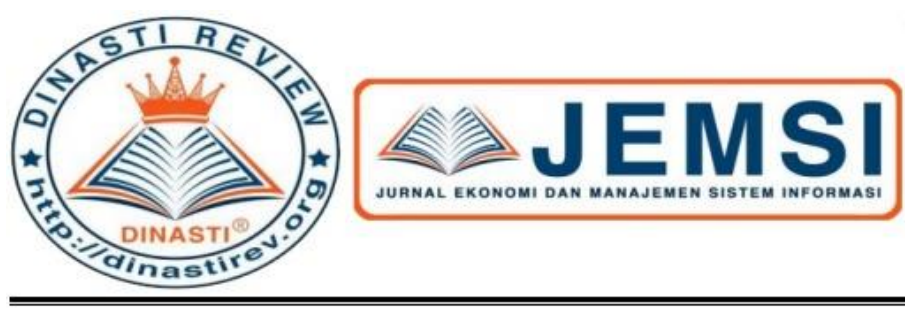

+62 878-9658-6407

087896586407

https://dinastirev.org/JEMS I (6)

editor@dinastirev.org (6)

\title{
BUSINESS ETHICS PADA PT.CONTROL SYSTEMS ARENA PARA NUSA
}

\section{Rintis Sukma Dewi}

Program Pasca Sarjana, Universitas Mercubuana, Jakarta, Indonesia

\begin{tabular}{|c|c|}
\hline $\begin{array}{c}\text { ARTICLE INFORMATION } \\
\text { Received: } 4 \text { April } 2020 \\
\text { Revised: } 14 \text { April } 2020 \\
\text { Issued: } 22 \text { April } 2020 \\
\text { Corresponding author: } \\
\text { Rintis Sukma Dewi } \\
\text { E-mail: enviro2_ntis@ yahoo.co.id }\end{array}$ & $\begin{array}{l}\text { Abstrak: Etika bisnis adalah aturan-aturan yang } \\
\text { menegaskan suatu bisnis boleh bertindak dan tidak boleh } \\
\text { bertindak. Aturan-aturan tersebut dapat bersumber dari } \\
\text { aturan tertulis maupun yang tidak tertulis. Jika suatu bisnis } \\
\text { melanggar aturan-aturan tersebut, sanksi akan diterima. } \\
\text { Sanksi tersebut dapat berbentuk langsung maupun tidak } \\
\text { langsung. Manajemen dan seluruh karyawan PT. Control } \\
\text { Systems Arena Para Nusa wajib mengikuti etika bisnis dan } \\
\text { pedoman perilaku yang berlaku. Dengan menerapkan etika } \\
\text { bisnis yang baik di dalam lingkungan perusahaan, dapat } \\
\text { membangun reputasi perusahaan yang baik di mata } \\
\text { pelanggannya. Perusahaan yang memiliki reputasi yang } \\
\text { baik di mata pelanggannya, dapat berpengaruh terhadap } \\
\text { keputusan pelanggan dalam membeli produk atau jasa } \\
\text { yang akan digunakannya. Reputasi yang baik dapat } \\
\text { meningkatkan keunggulan bersaing terhadap perusahaan } \\
\text { tersebut. Dengan menggunakan metode penelitian } \\
\text { kualitatif deskriptif menunjukkan bahwa penerapan etika } \\
\text { bisnis Pada PT. Control Systems Arena Para Nusa dapat } \\
\text { memengaruhi kualitas terhadap barang atau jasa yang } \\
\text { dihasilkan sehingga dapat diterima oleh pelanggan dan } \\
\text { dapat mencapai kepuasan pelanggan. } \\
\text { Kata Kunci:Etika Bisnis, Kualitas, Kepuasan Pelanggan }\end{array}$ \\
\hline
\end{tabular}




\section{PENDAHULUAN}

Reputasi sebuah perusahaan tergantung cara perusahaan tersebut bertindak. Dengan menerapkan etika bisnis (business ethics) yang baik di dalam lingkungan perusahaan dapat membangun reputasi perusahaan yang baik di mata pelanggannya. Perusahaan yang memiliki reputasi yang baik di mata pelanggannya tentunya akan berpengaruh terhadap keputusan pelanggan dalam membeli produk atau jasa yang akan digunakannya dan dapat meningkatkan keunggulan bersaing (competitive advantage) terhadap perusahaan tersebut. Keputusan pembelian dapat terjadi jika persepsi pelanggan yang dicapai tercapai dan bahkan melebihi harapan, berdasarkan kualitas produk, kualitas layanan, dan harga yang akan memengaruhi keputusan pembelian yang pada akhirnya akan berdampak pada keputusan pembelian (Anggita, R., \& Ali, H. 2017). Dengan meningkatnya kepercayaan pelanggan terhadap pelayanan dan kualitas produk atau jasa yang dihasilkan perusahaan berarti terdapat tingkat kepuasan pelanggan. Kepuasan pelanggan adalah perasaan senang atau kecewa seseorang yang berasal dari perbandingan antara kesannya terhadap kinerja (hasil) suatu produk dan harapanharapannya (Djaslim Saladin, 2003). Kepuasan pelanggan sendiri dapat dirasakan oleh pelanggan setelah pelanggan tersebut memiliki hubungan kerja sama dengan perusahaan dalam melakukan pembelian barang atau jasa dari perusahaan tersebut. Perusahaan yang memiliki reputasi yang baik dengan menerapkan etika bisnis yang baik tentu akan berpengaruh terhadap tingkat kepuasan pelanggannya

PT.Control Systems Arena Para Nusa atau yang biasa disingkat dengan PTCS merupakan sebuah perusahaan swasta nasional yang berdiri sejak tahun 1980 yang bergerak di bidang Proses Kontrol dan Instrumentasi. Reputasi PT. Control Systems Arena Para Nusa yang memiliki integritas adalah sangat penting serta merupakan hal yang mendasari hubungan perusahaan dengan semua pihak, khususnya pelanggan. Prinsip dari PT. Control Systems Arena Para Nusa adalah tidak memperbolehkan untuk mengorbankan integritas demi hasil. Tujuan yang hendak dicapai tidak diperbolehkan untuk menghalalkan segala cara. PT. Control Systems Arena Para Nusa sangat menjunjung tinggi perilaku karyawan yang sejalan dengan hukum dan etika ketika berhubungan dengan pelanggan, penyedia eksternal, pejabat pemerintah, maupun sesama karyawan perusahaan.

Di era globalisasi yang serba cepat dan teknologi yang semakin maju dan canggih ini, PT. Control Systems Arena Para Nusa menyadari bahwa persaingan di dalam dunia bisnis akan semakin ketat. Semua perusahaan berlomba-lomba berinovasi menghasilkan produk atau jasa yang memiliki kualitas yang terbaik. Jika perusahaan tidak dapat mengikuti perkembangan yang ada dan tidak menjaga kualitas produk atau jasa yang dihasilkannya perusahaan lambat laun akan ditinggalkan oleh pelanggannya. Dalam rangka menjaga dan mempertahankan kualitas produk atau jasa yang dihasilkan oleh perusahaan agar perusahaan mampu memenangkan kompetisi global dan tetap eksis di kalangan pelanggan yang sejalan dengan visi dan misi perusahaan, PT. Control Systems Arena Para Nusa menyadari pentingnya penerapan etika bisnis yang baik di lingkungan perusahaan. Etika bisnis ini tertuang dalam kebijakan kode etik perusahaan yang harus diikuti dan ditaati oleh semua karyawan PT. Control Systems Arena Para Nusa. Karyawan wajib mempelajari dengan seksama dan memahami sepenuhnya dengan harapan karyawan dapat menjaga reputasi perusahaan dengan baik. 


\section{KAJIAN PUSTAKA}

Menurut Keraf $(1998,14)$ etika berasal dari kata yunani ethos, yang dalam bentuk jamaknya berarti adat istiadat atau kebiasaan. Perpanjangan dari adat istiadat membangun suatu aturan kuat di masyarakat, yaitu bagaimana setiap tindak dan tanduk mengikuti aturan-aturan, dan aturan-aturan tersebut ternyata telah membentuk moral masyarakat dalam menghargai adat istiadat yang berlaku. Moral memang mampu memengaruhi seseorang dalam mengambil keputusan (Velasquez, 2005). Sehingga etika dan moralitas berbeda, etika perlu dipahami sebagai sebuah cabang filsafat yang berbicara mengenai nilai dan norma moral yang menentukan perilaku manusia dalam hidupnya.

Etika bisnis adalah aturan-aturan yang menegaskan suatu bisnis boleh bertindak dan tidak boleh bertindak, dimana aturan-aturan tersebut dapat bersumber dari aturan tertulis maupun yang tidak tertulis. Jika suatu bisnis melanggar aturan-aturan tersebut maka sanksi akan diterima. Dimana sanksi tersebut dapat berbentuk langsung maupun tidak langsung (Irham Fahmi;2013).

Sonny Keraf (1998) menjelaskan prinsip-prinsip etika bisnis sebagai berikut:

1. Prinsip otonomi merupakan sikap dan kemampuan yang dimiliki manusia dalam pengambilan keputusan dan melakukan tindakan berdasarkan kesadarannya terkait apa yang dianggapnya baik untuk dilakukan.

2. Terdapat tiga lingkup batasan kegiatan bisnis pada prinsip kejujuran yang dapat ditunjukkan dengan jelas bahwa bisnis tidak akan bertahan lama dan berhasil jika tidak didasari dengan kejujuran, yaitu kejujuran dalam memenuhi setiap persyaratan dalam perjanjian dan kontrak, kejujuran pada saat memberikan penawaran barang atau jasa dengan kualitas dan harga yang sebanding, dan yang terakhir adalah kejujuran dalam hubungan kerja intern di dalam sebuah lingkungan perusahaan.

3. Prinsip keadilan mengharuskan supaya setiap personel diperlakukan secara adil sesuai dengan aturan yang berlaku secara adil dan sesuai dengan kriteria yang rasional obyektif, dan dapat dipertanggungjawabkan.

4. Prinsip saling menguntungkan (mutual benefit principle) menuntut agar bisnis dijalankan sedemikian rupa sehingga menguntungkan semua pihak.

5. Diutamakan untuk dihayati sebagai tuntutan internal dalam diri pelaku bisnis atau perusahaan pada prinsip integritas moral supaya dapat menjalankan bisnis dengan tetap menjaga nama baik pimpinan, para karyawan, ataupun perusahaannya.

Adapun manfaat etika bisnis menurut Sutrisna (2010) adalah sebagai berikut:

1. Sebagai moralitas, etika bisnis membimbing tingkah laku manusia agar dapat mengelola kehidupan dan bisnis menjadi lebih baik.

2. Dapat mendorong dan mengajak orang untuk bersikap kritis dan rasional dalam mengambil keputusan berdasarkan pendapatnya sendiri, yang dapat dipertanggungjawabkannya.

3. Bisa memberikan pengarahan kepada masyarakat untuk dapat berkembang menjadi masyarakat yang tertib, teratur, damai, dan sejahtera dengan mematuhi norma-norma yang berlaku demi mencapai ketertiban dan kesejahteraan sosial. 
4. Sebagai ilmu pengetahuan, etika bisnis diberikan pemenuhan terhadap keingintahuan dan menuntut manusia untuk dapat berperilaku moral secara kritis dan rasional.

Keuntungan etika bisnis bagi para pembisnis menurut pendapat Sinour (2009), antara lain:

1. Adanya kesadaran bagi para pebisnis tentang adanya ukuran etis yang melekat di dalam perusahaan yang dibangun dipengruhi oleh adanya etika bisnis.

2. Etika bisnis dapat memberikan menambah kemampuan bagi para pebisnis untuk membuat pertimbangan-pertimbangan moral dan pertimbangan-pertimbangan ekonomis secara memadai.

3. Etika bisnis mampu memberikan arah yang tepat sasaran bagi para pembisnis pada saat akan menerapkan pertimbangan-pertimbangan moral-etis dalam setiap kebijakan dan keputusan bisnis demi tercapainya tujuan yang ingin dicapainya.

Von der Embse dan R.A.Wagley mengemukakan dalam artikel Advance management Journal (1988) yang berjudul Managerial Ethics Hard Decisions on Soft Criteria, bahwa terdapat tiga pendekatan dasar dalam merumuskan tingkah laku etika bisnis, di antaranya:

1. Utilitarian Approach menjelaskan bahwa setiap tindakan harus sejalan dengan konsekuensinya yaitu dalam bertindak seseorang semestinya mengikuti tata cara yang dapat memberikan manfaat sebesar-besarnya kepada masyarakat, dengan tata cara yang tidak membahayakan dan biaya terendah.

2. Individual Rights Approach menjelaskan bahwa setiap orang dalam tindakan dan kelakuannya memiliki hak dasar yang harus dihormati. Namun perbuatan ataupun tingkah laku tersebut harus dihindari jika diperkirakan akan menyebabkan terjadi benturan dengan hak orang lain.

3. Justice Approach menjelaskan bahwa setiap pembuat keputusan adalah berkedudukan sama dan di dalam memberikan pelayanan kepada pelanggannya baik secara perseorangan ataupun kelompok harus bertindak adil.

Peranan Etika dalam Bisnis (Hapzi Ali, 2020)

Etika berfungsi menggugah kesadaran moral pelaku bisnis untuk berbisnis secara baik dan etis didasari nilai-nilai luhur yang bermanfaat bagi konsumen, masyarakat dan demi menjaga nama baik bisnis sendiri dalam jangka panjang. Ada tiga dasar yang mendasari bisnis berlaku etis, yaitu ajaran agama (Tuhan yang maha esa), kepentingan sosial, dan perilaku pebisnis yang dinilai utama.

1. Ajaran Agama (Tuhan Yang Maha Esa)

Agama mengatakan bahwa sesudah kehidupan jasmani ini manusia akan hidup terus dalam dunia baka. Tuhan sebagai hakim Maha Agung akan menghukum kejahatan yang pernah dilakukan dan mengganjar kebaikkannya. Pandangan ini didasarkan pada imam kepercayaan, yang tentunya diharapkan setiap pebisnis akan dibimbing oleh iman kepercayaannya yang menjadi tugas agama mengajak pemeluknya untuk tetap berpegang pada motivasi moral.

2. Kontrak Sosial

Segala sesuatu yang dilakukan oleh seorang pebisnis akan berhubungan dengan tingkat kesejahteraan mayarakat, maka pebisnis dalam interaksi bisnisnya memiliki kontrak sosial dengan masyarakat tempat dimana ia berbisnis untuk selalu menciptakan kesejahteraan dalam kegiatan bisnisnya. Pandangan ini melihat perilaku manusia dalam perspektif sosial. 
Setiap kegiatan dilakukan bersama-sama dalam masyarakat, menuntut adanya normanorma dan nilai-nilai moral. Dengan demikian kehidupan kemasyarakatan senantiasa menjadi lebih sejahtera.

3. Keutamaan

Pebisnis sebagai manusia memiliki nilai mulia dan utama bila melaksanakan bisnisnya secara bermoral. Keutamaan sebagai ukuran untuk melakukan bisnis terbaik, merupakan penyempurnaan tertinggi kodrat manusia. Manusia yang berlaku etis adalah baik, baik secara menyeluruh materil dan spirituil.

Pebisnis harus melakukan sesuatu kebaikan, karena hal itu baik. Pebisnis harus berintegritas. Dalam bekerja, pebisnis boleh mencari keuntungan. Perusahaan merupakan organisasi sebagai alat untuk memperoleh keuntungan. Namun pebisnis atau perusahaan dikatakan tidak berintegritas, jika kegiatan mereka mengumpulkan kekayaan tanpa pertimbangan moral.

\section{METODE PENELITIAN}

Metode penelitian yang digunakan penulis adalah menggunakan metode kualitatif deskriptif, yaitu metode penelitian yang status sekelompok manusia, suatu objek, suatu kondisi, suatu sistem pemikiran, ataupun suatu kelas peristiwa pada masa sekarang dengan tujuan untuk mendeskripsikan, menggambarkan atau melukiskan sesuatu secara sistematis, faktual dan akurat mengenai fakta-fakta, sifat-sifat serta hubungan antar fenomena yang diselidiki (Nazir;2009). Metode kualitatif digunakan untuk mendapatkan data yang mendalam, suatu data yang digunakan mengandung makna (Sugiyono;2011). Ciri dari metode deskriptif adalah data yang dikumpulkan berupa kata-kata, gambar, dan tidak berupa angka. Data-data tersebut kemungkinan berasal dari hasil wawancara, catatan lapangan, foto, videotape, dokumen pribadi, catatan atau memo, dan dokumen yang bersifat resmi lainnya (Moleong;2013). Dalam hal ini penulis akan mendeskripsikan penerapan etika bisnis pada PT. Control Systems Arena Para Nusa.

\section{HASIL DAN PEMBAHASAN}

Perusahaan dalam rangka menjalankan pekerjaan dan menjaga reputasinya, manajemen dan seluruhkaryawan diwajibkan untuk mengetahui dan mematuhi kebijakan etika bisnis perusahaan dan pedoman perilaku.

1. Pembukuan yang Akurat

Kebijakan untuk mencatat semua transaksi dan menyimpan setiap pembukuan dengan baik sehingga dapat mencerminkan transaksi-transaksinya secara akurat. Manajemen dan seluruh karyawan dilarang memalsukan catatan dengan berbagai cara.

2. Penyuapan dan Praktik Bisnis Ilegal

Manajemen dan seluruh karyawan tidak diperbolehkan menawarkan atau memberikan apapun yang bernilai baik berupa uang dan/atau barang kepada pelanggan, penyedia eksternal, karyawan, atau pejabat pemerintah baik secara langsung ataupun melalui perantara yang dapat ditafsirkan sebagai upaya untuk mendorong pelanggan atau pihak ketiga guna mempergunakan pengaruhnya dengan tujuan untuk membantu perusahaan dalam memperoleh atau mempertahankan bisnis, menguntungkan perusahaan, dan menguntungkan perseorangan. Perusahaan juga tidak memperbolehkan pembayaran dalam jumlah kecil tertentu yang dikenal sebagai "fasilitative payment" kepada pegawai pemerintah yang tugasnya bersifat administrasi untuk mempercepat layanan yang memang sudah menjadi hak perusahaan.Perusahaan memberikan pengecualian terhadap kebijakan 
tersebut hanya berlaku bagi kondisi khusus demi menjaga keamanan dan kesehatan karyawan atau tanggungannya.

3. Hadiah Bisnis

Seluruh karyawan tidak diperbolehkan mencari, meminta, atau menerima pemberian hadiah, pembayaran uang, biaya, jasa, kesempatan, atau bantuan lainnya dengan tujuan menjalin bisnis terhadap perusahaan lain atau terhadap penyedia eksternal yang sedang berbisnis.Perusahaan tidak memperbolehkan penerimaan hadiah bisnis berupa uang tunai, saham, obligasi, atau hal-hal serupa seberapa pun jumlahnya.

Perusahaan memperbolehkan penerimaan hadiah bisnis dari perusahaan lain (vendor) berupa hadiah-hadiah tertentu dengan nilai kecil yang diberikan sebagai praktik bisnis yang umum dan dapat diterima sebagai hal yang wajar. Akan tetapi perusahaan tidak memperbolehkan seluruh karyawan meminta atau dengan cara apapun memohon hadiah, sumbangan ,atau donasi. Hadiah bisnis yang diperbolehkan untuk perusahaan lain berupa hadiah, bantuan, dan hiburan yang diperbolehkan diberikan kepada pihak lain oleh karyawan perusahaan adalah yang lazim dan sesuai dengan praktik bisnis yang baik serta dapat dipertanggungjawabkan.

Seluruh karyawan wajib melaporkan kepada pimpinannya atas hadiah-hadiah yang diterima atau diberikan yang dapat ditafsirkan sebagai pelanggaran atas kebijakan perusahaan.

4. Sumbangan Dana

Perusahaan mengharuskan setiap pemberian terhadap pemberian sumbangan dana yang wajar bagi kepentingan kemanusiaan, sosial, bencana alam, pendidikan, olahraga, asosiasi profesi/usaha harus dilakukan secara tertulis dan pada saat penyerahan sumbangan tersebut dibuktikan dengan tanda terima.

5. Informasi Konfidensial

Perusahaan tidak memperbolehkan seluruh karyawan ataupun mantan karyawan membuka rahasia dagang perusahaan atau informasi rahasia lainnya.

6. Konflik Kepentingan

Perusahaan tidak memperbolehkan seluruh karyawan memiliki investasi atau hubungan dengan organisasi lain yang dapat menempatkan dalam posisi konflik dengan kepentingan terbesar perusahaan, konflik kepentingan yang mungkin timbul yaitu:

a. Seorang karyawan atau rekan seorang karyawan yang memiliki atau mungkin memiliki kepentingan materi langsung ataupun tidak langsung dalam transaksi perusahaan.

b. Seorang karyawan yang terlibat di dalam proses tuntutan hukum yang menempatkan dirinya atau rekannya sebagai pihak lawan perusahaan atau memiliki kepentingan yang membahayakan perusahaan.

c. Seorang karyawan atau rekan karyawan yang memiliki kepentingan atau posisi tanggung jawab keuangan yang signifikan (staf, direktur, pemegang saham utama, mitra, atau pemilik) suatu pihak ketiga yang sedang berbisnis dengan perusahaan, sedang berusaha untuk berbisnis dengan perusahaan atau bersaing dengan perusahaan.

7. Pengiriman Material

Setiap permintaan pelanggan, perusahaan akan menyediakan jasa dan material yang berkualitas. Perusahaan akan memastikan terlaksananya pengiriman material dengan baik dan melakukan penyimpanan kualitas/spesifikasi atau jumlah/kualitas sesuai dengan sepengetahuan dan persetujuan pelanggan. Perusahaan akan memberikan tagihan untuk 
semua material dan jasa yang disediakan kepada pelanggan secara akurat. Selanjutnya setiap catatan inventaris yang akurat untuk semua pekerjaan harus disimpan. Catatan-catan tersebut harus cukup lengkap untuk mendukung jumah biaya yang seharusnya ditagihkan kepada pelanggan.

8. Lingkungan, Kesehatan, dan Keselamatan

Seluruh karyawan diharuskan untuk mematuhi undang-undang dan peraturan dalam hal perlindungan terhadap lingkungan dan keselamatan karyawan/pekerja perusahaan yang meliputi: kebijakan penyimpanan dokumen perusahaan terkait dengan urusan lingkungan, keselamatan dan kesehatan, semua pedoman dan prosedur lain yang diuraikan dalam panduan-panduan atau manual-manual yang diterbitkan oleh perusahaan.Setiap karyawan harus menggunakan praktik-praktik manajemen yang sesuai dan mekanisme pengendalian pencemaran lingkungan yang baik untuk mencegah timbulnya risiko bagi karyawan, kesehatan umum, dan lingkungan.

9. Kesetaraan Peluang

Perusahaan akan memberikan peluang kerja yang sama bagi semua orang tanpa memandang SARA (suku, agama, ras, dan adat-istiadat). Perusahaan membuat pengecualian untuk kebijakan ini hanya ketika mempekerjakan karyawan untuk posisi yang mempersyaratkan kemampuan fisik khusus dalam pelaksanaan fungsi-fungsi utama dari pekerjaan tersebut.

Perusahaan akan melakukan proses rekrutmen, membina, mempertahankan tenaga kerja yang berkompetensi tinggi, dan menggunakan seluruh sumber daya manusia secara kreatif, efektif, dan produktif untuk menjamin kelangsungan keberhasilan perusahaan. Perusahaan berkomitmen untuk menjalankan bisnis dengan menjunjung tinggi dan menghargai harga diri manusia dan nilai pribadi setiap individu.

10. Pengontrolan dan Pelaporan Keuangan

Seluruh karyawan harus mengikuti sistem dan prosedur akuntansi internal yang sesuai. Semua jenis transaksi akuntansi dan keuangan harus dilaporkan secara akurat dalam catatan keuangan dan laporan keuangan perusahaan.

Seluruh unit dan divisi operasional bertanggung jawab untuk mengimplementasikan prosedur pengontrolan yang akan memberikan jaminan yang baik terhadap transaksi yang dilaksanakan berdasarkan otorisasi pihak manajemen melalui pelaksanaan pencatatan transaksi dengan cara yang akan memungkinkan penyiapan laporan keuangan secara akurat yang sesuai dengan peraturan pemerintah.Pelaksanaan transaksi antara perusahaan dan anak-anak perusahaannya atau pihak manajemen harus dapat dipertanggungjawabkan dengan baik dan tertib, dan memastikan tidak ada transaksi yang tidak diungkapkan termasuk tanda terima dari atau pembayaran kepada pejabat atau pegawai pemerintah, tanda terima atas rabat/discount/pengembalian uang pembayaran, dan semua ketidaksesuaian (jika ada) yang bagaimanapun sifatnya yang berhasil dikenali dan harus segera dilaporkan kepada pimpinan.

11. Kemananan Data dan Penggunaan Komputer

Seluruh karyawan harus bertanggungjawab untuk melindungi keamanan terhadap informasi konfidensial milik perusahaan maupun pelanggan, keamanan komputer dan sistem informasi perusahaan, dan data dan informasi keuangan yang disimpan dalam sistem perusahaan. 
Perusahaan memikul tanggung jawab yang besar kepada pelanggan untuk melindungi keamanan dan integritas sistem jaringan komputer perusahaan dan data pelanggan. Oleh karena itu, seluruh karyawan diharuskan untuk menyadari adanya pihak ketiga yang bermaksud menimbulkan kerusakan pada perusahaan dapat mengintersepsi/menyelidiki adanya percakapan yang dilakukan oleh karyawan baik secara langsung atau melalui telepon, dokumen yang dibawa oleh karyawan, dan informasi yang diterima atau dikirimkan oleh karyawan melalui jaringan internet.

a. Melakukan Bisnis di Luar Negeri

Ketika melakukan bisnis di luar negeri, karyawan harus mempertimbangkan bahwa setiap percakapan, baik secara langsung maupun melelui telepon, dapat didengar orang lain, baik secara elektronik maupun lainnya. Dalam situasi demikian, karyawan harus mempertimbangkan kemungkinan melakukan diskusi urusan-urusan penting perusahaan di tempat umum dimana kemungkinan suatu percakapan disadap orang lain yang tidak berhak. Karyawan juga harus memastikan bahwa mereka tidak meninggalkan dokumen perusahaan tanpa terjaga kapan pun.

b. Penggunaan Komputer

Peralatan dan perangkat lunak yang dikeluarkan oleh perusahaan merupakan hak milik perusahaan dan disediakan hanya untuk tujuan bisnis yang dijalankan. Demikian pula, akses ke internet atau jaringan luar lainnya dengan menggunakan peralatan, saluran telepon, atau jaringan perusahaan, disediakan hanya untuk tujuan bisnis yang diizinkan.

c. Hak Cipta/Pemberian Lisensi

Karyawan perusahaan bertanggungjawab untuk menangani dengan baik bahan-bahan dan perangkat lunak yang dilindungi hak cipta dan lisensinya. Kecuali bila diizinkan secara eksplisit atau apabila ragu-ragu, tidak diperbolehkan mengkopinya. Seluruh karyawan harus memastikan sebelum menginstal suatu perangkat lunak apa pun agar mendapatkan persetujuan terlebih dahulu dari bagian IT perusahaan.

d. Surat Elektronik

Manajer memiliki akses terhadap pesan-pesan email semua bawahannya, email harus digunakan hanya untuk tujuan bisnis, pedoman mengenai memorandum atau surat antar kantor juga berlaku bagi email, dan data-data email tidak boleh disimpan lebih lama daripada yang dibutuhkan. Menghapus pesan email dari in box tidak berarti bahwa pesan tersebut telah terhapus dari file cadangan (back up).

e. Penggunaan Internet

Perusahaan membatasi penggunaan internet bagi seluruh karyawan hanya untuk tujuan perusahaan yang terkait dengan bisnis seperti berkomunikasi dengan pelanggan, penyedia eksternal, melakukan riset untuk topik-topik yang terkait, dan mencari informasi bisnis yang berguna. Semua kebijakan perusahaan yang ada berlaku bagi perilaku dalam berinternet, namun tidak terbatas pada hal-hal yang terkait dengan hak kekayaan intelektual, privasi, penyalahgunaan sumber daya perusahaan, pelecehan seksual, dan kerahasiaan/confindentiality.

f. Informasi Konfindensial

Informasi konfindensial seperti data keuangan perusahaan atau milik pelanggantidak boleh dikirimkan melalui internet atau kepada jaringan luar lainnya tanpa persetujuan sebelumnya dari pihak manajemen.

12. Hak Kekayaan Intelektual 
Seluruh karyawan diharuskan untuk melindungi hak kekayaan intelektual perusahaan dan seluruh karyawan tidak diperbolehkan melanggar hak pihak ketiga dalam hal hak kekayaan intelektual mereka.

a. Properti Milik Orang Lain

Perusahaan tidak memperbolehkan seluruh karyawan secara sadar menggunakan, melanggar, menghina, atau menggunakan secara tidak sepantasnya merek dagang, paten, rahasia dagang, atau teknologi hak milik sah (proprietary) pihak lain. Seluruh karyawan tidak diperbolehkan mengungkapkan rahasia dagang atau informasi konfindensial mengenai tempat kerja mereka sebelumnya.

b. Properti Milik Perusahaan

Seluruh karyawan harus melindungi hak kekayaan intelektual perusahaan dan menerapkan tindakan-tindakan pencegahan yang diperlukan, seperti:

- Secara fisik mengamankan semua informasi hak cipta ketika tidak ditunggui, tidak meninggalkan $\mathrm{CD}$ data atau kertas kerja di atas meja dan dilarang meninggalkan komputer dalam keadaan membuka file-file yang dilindungi password, terutama selama makan siang dan setelah jam kerja

- Menyingkirkan kertas tulis (flip-chart) dan menghapus papan tulis/whiteboard setelah pertemuan usai

- Memberi keterangan kerahasiaan yang sesuai untuk semua informasi hak cipta untuk memberi tahu mereka yang menangani informasi tersebut bahwa bahan tersebut bersifat rahasia dan dibutuhkan perlindungan khusus

- Membatasi akses karyawan diperuntukkan hanya bagi karyawan yang memang perlu tahu.

- Memberikan batasan akses pihak ketiga hanya bagi mereka yang memiliki otorisasi tertulis

- Memberikan laporan semua akses tanpa izin oleh karyawan atau pihak ketiga

- Menggunakan password pada komputer dan menjaga baik-baik kerahasiaan password tersebut

Peralatan dan perangkat lunak yang dikeluarkan oleh perusahaan merupakan hak milik perusahaan dan disediakan hanya untuk tujuan bisnis yang diizinkan.

13. Bisnis di Luar Negeri

Seluruh karyawan di perusahaan diharuskan untuk mematuhi hukum NKRI dan negara di mana karyawan ditugaskan. Tidak seorang karyawan pun diperbolehkan mencoba menghindari hukum-hukum tersebut secara langsung maupun tidak langsung. Setiap kemungkinan pelanggaran terhadap hukum yang berlaku harus segera dilaporkan kepada pimpinan perusahaan dan kegiatan-kegiatan yang terkait dengan transaksi tersebut harus dihentikan sampai pimpinan memberikan pedoman tertulis yang menyatakan bahwa transaksi tersebut tidak melanggar hukum.

14. Kebijakan Anti Pelecehan

Perusahaan menjunjung tinggi komitmen untuk memelihara lingkungan kerja yang bebas dari tindakan diskriminasi dan pelecehan di mana semua individu diperlakukan dengan hormat dan bermartabat.

15. Sumbangan Politik 
Perusahaan tidak memperbolehkan seluruh karyawan perusahaan baik secara langsung maupun melalui perantara, menggunakan dana atau sumber daya perusahaan untuk memberikan sumbangan kepada partai politik maupun pejabat partai.

16. Penyimpanan Catatan

Perusahaan mengharuskan ditetapkannya prosedur untuk mencapai tujuan penyimpanan catatan berikut ini:

a. Melakukan penyimpanan catatan aktif dan inaktif dalam fasilitas penyimpanan yang sesuai

b. Mengidentifikasi dan melindungi catatan penting dan historis

c. Mikrofirm dan elektronik dapat digunakan untuk aplikasi yang sesuai

d. Mengikuti pedoman hukum dan pedoman internasional yang berlaku, termasuk ketentuan hukum yang terkait dengan pengajuan tuntutan hukum, penyelidikan pemerintah, dan audit yang diwajibkan undang-undang

e. Penyimpanan catatan untuk jangka waktu yang ditentukan menurut jadwal penyimpanan catatan perusahaan

f. Mendorong penghancuran rutin catatan yang sudah tidak lagi diperlukan untuk operasional apabila penyimpanannya tidak diwajibkan oleh hukum atau jadwal penyimpanan catatan

17. Pelaporan, Penyelidikan, dan Tindakan Disiplin dalam Kaitannya dengan Pelanggaran Kebijakan

Seluruh karyawan yang mengetahui adanya pelanggaran yang nyata atas kebijakan perusahaan harus dilaporkan pelanggaran tersebut. Hal ini meliputi pelanggaran kebijakan-kebijakan yang ditetapkan dalam pedoman kode etik perusahaan, manual, atau pedoman lain yang dikeluarkan oleh perusahaan.

Setiap karyawan diwajibkan untuk bekerjasama dalam penyelidikan perusahaan. Karyawan diharapkan untuk memberikan informasi dan dokumentasi, jika diminta oleh perusahaan, di samping ikut serta dalam wawancara yang dilakukan oleh perusahaan atau perwakilan yang ditunjuk oleh perusahaan untuk melakukan penyelidikan.

PT. Control Systems Arena Para Nusa sebagai perusahaan yang memiliki integritas dalam menjaga reputasi perusahaan yang mendasari hubungan perusahaan dengan semua pihak, khususnya pelanggan. Perusahaan berkomitmen untuk memenuhi tanggung jawab moral dan tanggung jawab sosial perusahaan dalam mencapai tujuannya sesuai dengan visi dan misinya. Perusahaan mempersyaratkan seluruh karyawan dalam melakukan pekerjaan harus didasari dengan penuh rasa tanggung jawab dan beretika, menghormati dan menaati undangundang larangan praktik monopoli \& persaingan usaha tidak sehat, undang undang perseroan terbatas, undang undang pemberantasan tindak pidana korupsi, standar akuntansi yang berlaku, dan lain-lain. Segala perbuatan manajemen dan seluruh karyawan harus sejalan dengan hukum, kebijakan etika bisnis perusahaan, dan pedoman perilaku.

Setiap pelanggaran atas kebijakan-kebijakan yang berlaku dapat membuat perusahaan dan seluruh karyawan dikenai hukuman, denda, dan/atau tuntutan ganti rugi. Karyawan yang melanggar hukum dapat dituntut secara pidana dan dapat dituntut pertanggungjawabannya oleh perusahaan atas kerugian yang ditimbukannya sebagai akibat dari pelanggaran tersebut.

Seluruh karyawan yang lalai untuk melaporkan pelanggaran atau memberikan informasi lebih lanjut perihal suatu pelanggaran akan dikenai sanksi yang sesuai. Tindakan 
disipliner meliputi kemungkinan pemutusan hubungan kerja. Setiap karyawan yang membuat tuduhan palsu pelanggaran akan dikenai tindakan disipliner yang sama dengan mereka yang lalai untuk melaporkan atau memberikan informasi mengenai suatu pelanggaran.

PT. Control Systems Arena Para Nusa berusaha untuk memberikan pelayanan terbaik bagi setiap permintaan pelanggannya. Pelayanan tersebut meliputi penerimaan permintaan penawaran dari pelanggan, penerimaan permintaan pembelian dari pelanggan, pelaksanaan tinjauan kontrak pekerjaan dan komersial dari pelanggan, pelaksanaan perencanaan pekerjaan dari pelanggan, pelaksanaan pekerjaan, pelaksanaan monitoring penyelesaian terhadap pekerjaan yang diterimanya termasuk dalam pelaksanaan pengujian, pelaksanaan serah terima hasil pekerjaan kepada pelanggan, sampai dengan tahap layanan purna jual. Sebagaimana menurut Thomas A. Ganon (2004), yang menyatakan bahwa garansi ditunjukkan untuk meyakinkan konsumen bahwa produk dalam keadaan baik atau bebas dari kerusakan karena ketidaktelitian dalam proses produksi atau karena penggunaan material yang kurang baik dan berlaku untuk jangka waktu tertentu. Perusahaan akan menerima setiap keluhan pelanggan, melaksanakan penanganan keluhan pelanggan sehingga mencapai kepuasan pelanggan. Tujuan perusahaan memberikan layanan purna jual kepada pelanggan sebagai bentuk jaminan terhadap kualitas barang dan/atau jasa.

Menurut Davidov (2003), penanganan keluhan yang baik tidak hanya membawa pelanggan kepada peningkatan keinginan untuk melakukan pembelian berulang, tetapi juga menurunkan rekomendasi yang negatif dari mulut ke mulut dan meningkatkan rekomendasi yang positif dari mulut ke mulut sehingga dapat memberi keuntungan bagi perusahaan. Maxham dan Netemeyer (2002) menemukan keterkaitan antara penanganan keluhan terhadap keinginan konsumen untuk menggunakan produk tersebut kembali (repurchase intention). Penanganan keluhan pelanggan yang menjadikan pelanggan merasa puas, pelanggan dapat melakukan pembelian kembali dan bahkan dapat memberikan rekomendasi dari mulut ke mulut yang lebih posisitif. Karena kualitas barang dan/atau jasa yang baik akan mencerminkan reputasi perusahaan yang baik pula.

PT. Control Systems Arena Para Nusa Dalam upaya untuk mengetahui tingkat kepuasan pelanggan, perusahaan melakukan pengukuran kepuasan pelanggan pada setiap akhir penyelesaian pekerjaan yang dilakukannya.Selanjutnya akan dilakukan pembuatan analisa terhadap hasil pengukuran kepuasan pelanggan tersebut agar dapat dilakukan tindakan perbaikan dan pencegahan untuk meningkatkan kualitas terhadap barang dan/jasa yang dihasilkan guna untuk mencapai kepuasan pelanggan.

Tujuan utama dari sebuah aktivitas bisnis, tidak terkecuali PT. Control Systems Arena Para Nusa adalah tercapainya kepuasan pelanggan. Kepuasan yang dirasakan oleh pelanggan tidak terlepas dari diterapkannya etika bisnis dalam sebuah aktivitas bisnis. PT. Control Systems Arena Para Nusa dalam melaksanakan tiap-tiap tahap pekerjaan harus sejalan dengan hukum yang berlaku, kebijakan etika perusahaan, dan pedoman perilaku. 
Grafik 1. Penilaian kepuasan pelanggan untuk pekerjaan jasa periode Januari-Juli 2019 PENILAIAN KEPUASAN PELANGGAN UNTUK PEKERJAAN JASA PERIODE JANUARI-JULI 2019 (PENILAIAN 1-4)

$1=$ POOR EXPECTATION, 2 =BELOW EXPECTATION, 3=EXCEED EXPECTATION, $4=0$ OUTSTANDING

- Service Support employee are helpful and cooperative

Easily administration process

- Timeliness of Tech Support delivery to ste

- Tech Support employee had competent and strong knowledge of the product

- Availability TSE tools in handling problems
- Quickly respond to any complaints that you inform Easily of warranty serviceclaim process

- Tech Support employee are listened carefully

- Tech Support employee had solution to hand ling problems

- Quality of TSE service report In providing solutions
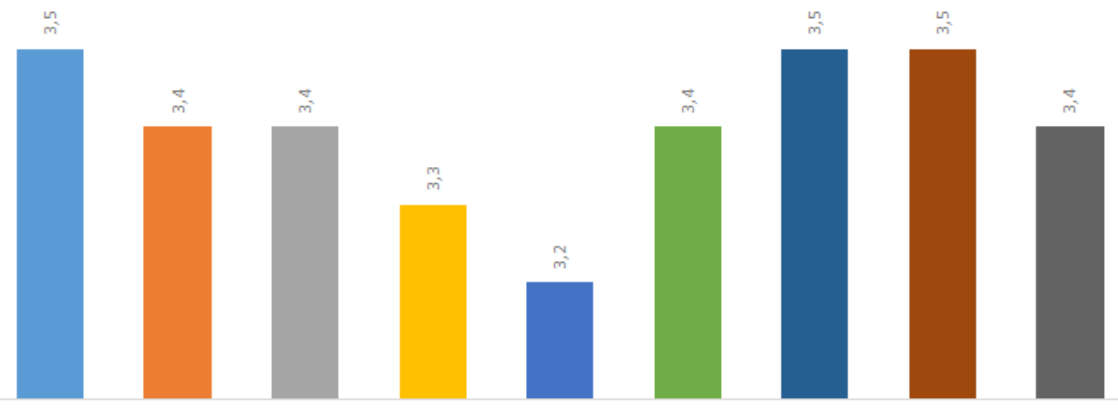

NILAI RATA-RATADARI 65 PELANGGAN

Grafik 2. Penilaian kepuasan pelanggan untuk pekerjaan proyek periode Januari-Juli 2019 PENILAIAN KEPUASAN PELANGGAN UNTUK PEKERJAAN PROYEK PERIODE JANUARI-JULI 2019 (PENILAIAN 1-5)

1=WELL BELOW EXPECTATION, 2 =BELOW EXPECTATION, 3=MET EXPECTATION, $4=$ ABOVE EXPECTATION, $5=$ EXCEEDED EXPEXTATION
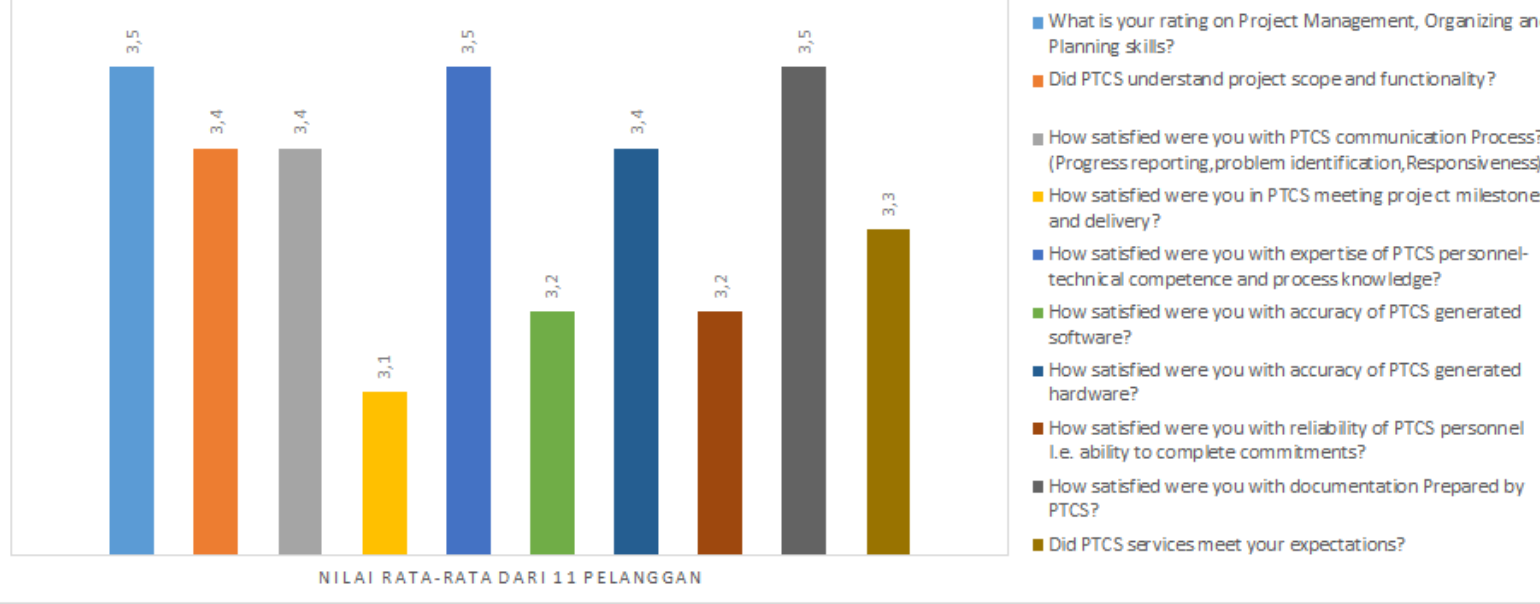

Berdasarkan data hasil penilaian kepuasan pelanggan untuk pekerjaan jasa periode Januari-Juli 2019 menunjukkan nilai rata-rata penilaian kepuasan pelanggan berada pada angka 3 exceed expectation dan hasil penilaian kepuasan pelanggan untuk pekerjaan proyek periode Januari-Juli 2019 menunjukkan nilai rata-rata penilaian kepuasan pelanggan berada pada angka 3 met expectation. Hal ini menunjukkan bahwa penerapan etika bisnis perusahaan berpengaruh terhadap kualitas barang atau jasa yang dihasilkan dapat diterima oleh pelanggan. 


\section{KESIMPULAN DAN SARAN}

\section{Kesimpulan}

1. PT. Control Systems Arena Para Nusa telah menerapkan etika dalam melakukan bisnisnya sehingga terciptanya reputasi perusahaan yang baik di mata pelanggannya. Reputasi perusahaan yang baik akan berpengaruh terhadap keputusan pelanggan dalam membeli produk atau jasa yang akan digunakannya dan dapat meningkatkan keunggulan bersaing (competitive advantage) terhadap perusahaan tersebut.

2. Penerapan etika bisnis Pada PT. Control Systems Arena Para Nusa berpengaruh terhadap kualitas barang atau jasa yang dihasilkannya yang dapat diterima oleh pelanggan sehingga mencapai kepuasan pelanggan.

3. PT. Control Systems Arena Para Nusa berkomitmen untuk memenuhi tanggung jawab moral dan tanggung jawab sosial perusahaan dalam mencapai tujuannya sesuai dengan visi \& misi perusahaan.

\section{Saran}

1. Untuk menghindari pelanggaran-pelanggaran yang mungkin terjadi, PT. Control Systems Arena Para Nusa harus konsisten dalam menjalankan etika bisnisnya karena setiap pelanggaran tersebut dapat membuat perusahaan dan seluruh karyawan yang melakukan pelanggaran dapat dikenai denda, hukuman, dan atau tuntutan ganti rugi.

2. Setiap atasan harus memastikan bahwa bawahannya mengetahui dan mematuhi kebijakankebijakan yang ada. Setiap kebijakan-kebijakan yang ada harus disosialisasikan secara menyeluruh dan dimengerti oleh seluruh karyawan.

3. Dalam rangka menjalankan usaha bisnisnya dan untuk mengurangi risiko kegagalan bersaing dalam era globalisasi ini, perusahaan harus meningkatkan etika bisnis yang baik dalam pelayanan dan lebih menjaga kekompakan antar sesama pihak internal. 


\section{DAFTAR RUJUKAN}

Ali, Hapzi. 2020. Modul Business Ethic \& GG. Universitas Mercu Buana. Jakarta.

Anggita, R., \& Ali, H. (2017). The Influence of Product Quality, Service Quality and Price to Purchase Decision of SGM Bunda Milk (Study on PT. Sarihusada Generasi Mahardika Region Jakarta, South Tangerang District). A (Multidisciplinary Journal)

Davidow, M. 2003. Have You Heard the Word? The Effect of Word of Mounth on Perceived Justice, Satisfaction and Repurchase Intentions Following Complaint Handling, Journal of Consumer Satisfaction, Dissatisfaction and Complaining Behavior. Vol. 16, pp.67-79.

Davidow, M. 2003. Organizational Responeses To Customer Complaints: What Works And What Doesn't. Journal of Service Research . Vol. 5, No.3, pp.225-250.

Embse,V.D., R.A. Wagley. 1998. Managerial Ethics Hard Decisions on Soft Criteria. Advance management Journal.

Fahmi, Irham. 2013. Etika Bisnis: Teori Kasus, dan Solusi. Bandung: Alfabeta.

Keraf, Sonny. 1998, Etika Bisnis (Tuntutan dan Relevansinya), Yogyakarta: Kanisius.

Manuel G. Velasquez. 2005, Etika Bisnis Konsep dan Kasus, (Alih Bahasa Ana Purwaningsih et.al), Yogyakarta: Andi.

Maxham, J. G., Richard, G., Netemeyer. 2002. Modeling Customer Perceptions of Complaint Handling Over Time: The Effects of Perceived Justice on Satisfaction and Intent. Journal of Retailing. Vol. 78, No.4, pp.239-252.

Moleong, L.J. 2013. Metode Penelitian Kualitatif (edisi revisi). Bandung: PT Remaja Rosdakarya.

Nazir, Moh. 2013. Metode Penelitian. Bogor: Ghalia Indonesia.

Saladin, Djaslim. 2003, Intisari Pemasaran dan Unsur-unsur Pemasaran, Cetakan Ketiga, Bandung : Linda Karya.

Sugiyono. 2011. Metode Penelitian Pendidikan Pendekatan Kuantitatif, Kualitatif, dan R \& D. Bandung: Alfabeta.

Sinour, Y.L. 2009. Etika bisnis. Jakarta: Yayasan Pustaka Obor Indonesia.

Sutrisna, D. 2010. Etika Bisnis: Konsep Dasar Implementasi dan Kasus. Bali: Udayana University Press. 